\title{
Malignant Ovarian Granulosa Cell Tumour in a Ewe
}

\author{
Tanja Švara, Mitja Gombač, Polona Juntes, Milan Pogačnik \\ Institute of Pathology, Forensic and Administrative Veterinary Medicine, Veterinary Faculty, \\ University of Ljubljana, Slovenia \\ Received June 2, 2008 \\ Accepted November 12, 2008
}

\begin{abstract}
We describe a rare case of malignant granulosa cell tumour in an adult ewe, euthanised due to progressive weight loss. Necropsy examination revealed a neoplastic enlargement of the right ovary, multifocal neoplastic masses in the lung and spleen, and severe enlargement of mediastinal and iliacal lymph nodes. Histopathology of the right ovary revealed a malignant ovarian granulosa cell tumour with metastases to the lung, spleen, and mediastinal and iliacal lymph nodes. Immunohistochemistry confirmed histopathological diagnosis. Neoplastic cells reacted positively for CK MNF 116 and vimentin and were negative for CK 7 and desmin. To our knowledge this is the first report of a malignant granulosa cell tumour in ewe.
\end{abstract}

Ewe, granulosa cell tumour, histopathology, immunohistochemisty, metastases, ovary

Granulosa cell tumour is a type of sex cord-stromal tumour, composed primary of neoplastic granulosa cells, but often also of theca cells and fibroblasts (Kennedy et al. 1998).

These tumours represent the most common ovarian tumours in the cow and mare; they are infrequent in the queen and rare in other domestic animals. They are usually benign, however granulosa cell tumours in queens, bitches and cows are considered more malignant than in mares (Norris et al. 1969; Sobocanec et al. 1996; MacLachlan and Kennedy 2002).

The neoplastic granulosa cells that resemble the granulosa cells of the follicle are most frequently arranged in micro- and macrofollicular, insular, trabecular, and diffuse patterns. A combination of different patterns is often expressed in a single tumour. Call-Exner bodies, which are small spaces filled with watery or hyaline eosinophilic material and surrounded by granulosa cells in a rosette arrangement, are most often in the microfollicular pattern (Kennedy et al. 1998). Histopathological distinction between various ovarian tumours is easy in most cases; however, poorly differentiated ovarian tumours require the use of immunohistochemistry. Granulosa cell tumours usually stain positive for $\alpha$-inhibin, vimentin and calretinin, and negative for cytokeratin 7 (CK 7), epithelial membrane antigen (EMA) and placental alkaline phosphatase (PLAP) (Ashorn et al. 1988; McCluggage and Young 2005; Riccardi et al. 2007).

Only few cases of benign granulosa cell tumours have been described in ewes (Cordes and Shortridge 1971; McEntee 1990; Smith et al. 1999; Gardner et al. 2005).

We describe the pathomorphologic findings in a ewe with malignant ovarian granulosa cell tumour and metastases to the spleen, lung, and mediastinal and iliacal lymph nodes. To our knowledge this is the first report of malignant granulosa cell tumour in a ewe.

\section{Materials and Methods}

An adult, five-year-old ewe, weighing $35 \mathrm{~kg}$, crossbred between Istrian pramenka (one of the four autochthonous Slovenian breeds) and Bosnian pramenka was euthanised due to progressive weight loss and subsequently presented for necropsy.

Samples of tumours of the right ovary, lung, spleen, mediastinal and iliacal lymph nodes were collected for the histopathological and immunohistochemical examination and promptly fixed in 10\% neutral-buffered formalin.

Address for correspondence:

Tanja Švara, D.V.M., M.Sc.

Institute of Pathology, Forensic and Administrative Veterinary Medicine

Veterinary Faculty, University of Ljubljana,

Gerbiceva 60, 1000 Ljubljana, Slovenia
Phone: +38614779152

Fax: + 38612834091

E-mail: tanja.svara@vf.uni-lj.si

http://www.vfu.cz/acta-vet/actavet.htm 
Fixed samples were routinely embedded in paraffin, cut into $4 \mu \mathrm{m}$ thick sections, stained with haematoxylin and eosin and examined with light microscope.

Immunohistochemical staining was performed on deparafinized, $4 \mu \mathrm{m}$ thick tissue sections of neoplastic ovary. Antigen retrieval for CK MNF 116, CK 7, desmin and vimentin was accomplished by treatment of sections in a citrate buffer $(\mathrm{pH}=6.0)$ in a microwave oven for $10 \mathrm{~min}$. For CK 7 staining, the tissue was afterwards digested with Protease 2 (Ventana) for $4 \mathrm{~min}$. Tissue sections for alfa-inhibin staining were pre-treated for antigen epitope retrieval by microwaving in EDTA buffer $(\mathrm{pH}=9.0)$ for $25 \mathrm{~min}$. Sections were stained in autostainer apparatus (DAKO). Endogenous peroxidase was blocked for $30 \mathrm{~min}$ in the Peroxidase-Blocking Solution, Dako REAL TM (DAKO). Sections were incubated for one hour at room temperature with antibodies against inhibin (monoclonal mouse anti- human antibody, DAKO, diluted 1 : 20), CK MNF 116 (monoclonal mouse anti- human antibody, DAKO, diluted $1: 100$ ), CK 7 (monoclonal mouse anti-human antibody, DAKO, diluted 1:100), vimentin (monoclonal mouse anti-human antibody, DAKO, diluted $1: 25$ ) and desmin, clone D33 (monoclonal mouse antihuman antibody, DAKO, diluted $1: 100$ ). After washing, sections were incubated for 30 min with peroxidaselabelled polymer-HRP conjugated to goat anti-rabbit immunoglobulins (Envision + System-HRP-DAB, DAKO, Carpinteria, CA). Staining was completed by incubation with 3, 3' diaminobenzidine chromogen solution (part of the Envision kit). The sections were then counterstained with haematoxylin, dehydrated and mounted. Negative control included incubation with DAKO Cytomation Antibody Diluent (DAKO) without the primary antibody. Sections of normal sheep ovary were used for positive controls.

\section{Results}

Gross pathology

The necropsy of ewe disclosed severe emaciation. The right ovary was enlarged, with the dimensions of $7 \times 5 \times 3.5 \mathrm{~cm}$ in length, width and thickness, respectively, oval shaped, and firm. It had irregularly lobulated, smooth, glistening, greyish-white surface with multifocal haemorrhages. The cut surface was finely granular and greyish-white with large areas of haemorrhages (Plate VII, Fig. 1). The left ovary was of normal size and shape. Large neoplastic mass, measuring $5 \mathrm{~cm}$ in diameter was found on the margo obtusus of the right caudal pulmonary lobe and several smaller neoplastic nodules, up to $2 \mathrm{~cm}$ in the diameter, were scattered on all pulmonary lobes. Neoplastic mass and all nodules were firm, greyishwhite, smooth, well demarcated, with bulged cut surface. Several soft, reddish-grey neoplastic nodules, up to $3 \mathrm{~cm}$ in diameter, protruded above the spleen surface. Nodules with reddishgrey, granular, and bulged cut surface were distinctly separated from spleen parenchyma (Plate VII, Fig. 2). Mediastinal and iliacal lymph nodes were enlarged, greyish-white, smooth and firm, with greyish-white, smooth and bulged cut surface. Uterus and both uterine horns were normal. No metastases were macroscopically found in other organs.

\section{Histopathology}

Histologically, the healthy tissue of the right ovary was totally replaced by tumour cells, resembling granulosa cells. Broad bands of fibrovascular stroma divided encapsulated neoplastic mass into lobules of different sizes and shapes; however, the amount of stroma inside lobules was scanty. The tumour showed heterogeneous histological pattern with tumour cells arranged in follicles and islands (Plate VIII, Fig. 3). Some tumour cells grew infiltratively into fibrovascular stroma, where they formed irregular rows and follicles.

Tumour cells were small, pleomorphic, ovoid, with indistinct cellular borders, and scanty, finely granular, eosinophilic cytoplasm. Their nuclei showed moderate degree of pleomorphism and anisokaryosis; they were round to ovoid, hyperchromatic, with inconspicuous nucleoli. Mitotic figures were rare. Multifocally, specific radial aggregations of tumour cells around central eosinophilic material and pycnotic nuclei, so-called CallExner bodies, were noticed (Plate VIII, Fig. 4).

Large groups of neoplastic cells grew into stromal lymph vessels, blocking the flow of the lymph, causing dilatation of lymphatics and oedema of the surrounding tissue. Large areas of necrosis and haemorrhages were multifocally observed in the tumour.

Neoplastic masses in the lung, spleen, mediastinal and iliacal lymph nodes consisted of cells similar to those in the right ovary. Secondary tumours were unencapsulated, poorly demarcated, with infiltrative growth. In contrast to the primary tumour, fibrous stroma in 
the metastases was more abundant. Tumour cells were found within the lymph vessels of all organs with secondary tumours - lymph nodes and lung and also in the pulmonary blood vessels.

The neoplasia of the right ovary was diagnosed as a malignant granulosa cell tumour with extensive metastases to the lung, spleen, mediastinal and iliacal lymph nodes.

\section{Immunohistochemistry}

The antibody against inhibin produced a negative result with paraffin sections of both normal and neoplastic ovary.

Immunohistochemical staining for CK MNF 116, antigen expressed in a wide spectrum of keratins, gave a strong positive cytoplasmic reaction in the neoplastic ovary. The percentage of positive-labelled neoplastic cells ranged from $10 \%$ to $50 \%$ in different parts of the tumour.

The tumour showed a positive reaction also for vimentin. A strong cytoplasmic reaction was found in endothelial cells of vascular stroma and in 10 to $20 \%$ of neoplastic cells. The tumour reacted negative for CK 7 and desmin.

The results of immunohistochemical examination confirmed previous histopathological diagnosis.

\section{Discussion}

Progressive weight loss was the only clinical sign observed in our case of malignant granulosa cell tumour in a ewe, in contrast to previously described cases of these tumours e.g. in mares and a bitch where a variety of clinical signs were described, for example: lameness, udder development, lactation and anorexia (Gardner et al. 2005), progressive weight loss, diarrhoea and depression (Patrick et al. 2003), anorexia (Sabocanec et al. 1996; Patrick et al. 2003), and lameness (Gift et al. 1992). Production of hormones in the neoplastic ovary may result in behavioural abnormalities and alterations in the oestrus cycle (Stabenfeldt et al. 1979).

Ovarian tumours are common in domestic animals, with rare incidence in ewes. According to the report of McEntee (1990) amongst 498 cases of ovarian neoplasms found during necropsy over a 33 year period, 276 were found in dogs, 139 in horses, 22 in cats, seven in pigs, one in a goat and one in a sheep. Three cases of granulosa cell tumour were determined in a survey of 256 cases of neoplasms of sheep (Cordes and Shortridge 1971). A survey of 9970 reproductive tracts from cull ewes and 23536 tracts from nulliparous sheep revealed one case of granulosa cell tumour (Smith et al. 1999), and another case of granulosa cell tumour in a ewe has been reported by Gardner et al. (2005).

Granulosa cell tumours are usually benign. Metastases are rare, most often found in queens, bitches and cows, only rarely in mares (Norris et al. 1969; Gift et al. 1992; Sobocanec et al. 1996; MacLachlan and Kennedy 2002), however, they have not been described in ewes. Metastases were usually located in the liver, omentum, cranial lymph nodes, kidneys, adrenal glands, intestines, peritoneum, and various abdominal and thoracic lymph nodes (Norris et al. 1969; Gift et al. 1992; Sobocanec et al. 1996; Patrick et al. 2003). In our case, the tumour revealed high metastatic potential, and formed numerous metastases in the lung, spleen, mediastinal and iliacal lymph nodes.

Histopathological appearance of neoplasm was consistent with a granulosa cell tumour. The finding of cellular anaplasia, foci of necrosis and/or haemorrhages, and vascular invasion by tumour cells were in accordance with previously described characteristics of malignant sex-cord stromal tumours (Kennedy et al. 1998; MacLachlan and Kennedy 2002). However, in contrast to previously described characteristics of malignant tumours, mitotic figures were rare in our case.

Call-Exner bodies, which are a useful diagnostic feature (MacLachlan and Kennedy 
2002), were also established in our case. Gardner et al. (2005) described the formation of lobules with central amphophilic material, too. This pattern of differentiation is frequently observed in early stages of bovine neoplasms, but is less common in other species and in large tumours (Kennedy and Miller 1993).

Histopathological diagnosis of granulosa cell tumours is easy in most cases. However, poorly differentiated granulosa cell tumours may be confused with ovarian epithelial tumours (Pelkey et al. 1998; Riccardi et al. 2007). Differentiation between these two types of tumours has great prognostic importance, since ovarian epithelial tumours are frequently malignant and metastatic (Riccardi et al. 2007). Granulosa cell tumours usually stain positive for $\alpha$-inhibin, vimentin and calretinin (Ashorn et al. 1988; McCluggage and Young 2005; Riccardi et al. 2007). Inhibin is a normal glycoprotein secretory product of granulosa cells that decreases pituitary secretion of follicle stimulating hormone (FSH) (Bernard et al. 2001) and is known as a sensitive marker for granulosa cell tumours (Pelkey et al. 1998). Staining for inhibin was negative in normal and neoplastic ovary, leading to the conclusion that the antibody, which was raised against the human antigen, is not appropriate for detection of this antigen in ovine paraffin embedded tissues. To our knowledge, the antibody against ovine alpha inhibin is not commercially available yet.

Cytokeratins are intermediate filaments, found in epithelial cells and tumours, which arise from this type of cells. Using an antibody that detects a wide spectrum of cytokeratins $(\mathrm{CK})$, positive reaction was found in neoplastic cells in our case; the finding is similar to other authors' observations (Costa et al. 1994; Riccardi et al. 2007). However, one of the cytokeratins, cytokeratin 7 , is selectively expressed in healthy and neoplastic ovarian surface epithelium and is a useful immunohistochemical marker for the differentiation of epithelial ovarian tumours from granulosa cell tumours (Ramaekers et al. 1990; Riccardi et al. 2007). In our case there was a negative reaction for CK 7.

The tumour also reacted positively for vimentin. Vimentin is usually detected in granulosa cell tumours and other ovarian tumours and therefore not a useful marker for differentiation among them (Vang et al. 2004; Riccardi et al. 2007). Negative immunohistochemical reaction for desmin in this case is in accordance with the results of equal reactions, performed in other cases of granulosa cell tumours (Costa et al. 1994).

In conclusion, to our knowledge this is the first report of malignant granulosa cell tumour in a ewe with metastases to the lung, spleen, mediastinal and iliacal lymph nodes.

\section{Zhoubný nádor buněk membrana granulosa vaječníku bahnice}

V této studii je popsán vzácný prrípad výskytu zhoubného nádoru buněk membrana granulosa vaječníku u dospělé bahnice, kterou bylo nutno utratit pro progresivní ztráty hmotnosti. Ze vzorků odebraných během pitvy a patologického vyšetření bylo zjištěno neoplastické zvětšení pravého vaječníku, mnohočetná ložiska nádorové tkáně v plicích a ve slezině, rozsáhlé zvětšení mediastinálních a kyčelních mízních uzlin. Histopatologickým vyšetřením tkáně pravého vaječníku byl prokázán zhoubný nádor buněk membrana granulosa s četným rozsevem metastáz do plic, sleziny, mízních uzlin mediastinálních a iliakálních. Tato diagnóza byla potvrzena imunohistochemickým vyšetřením. Neoplasticky změněné buňky vykazovaly pozitivní reakci na CK MNF 116 a vimentin a negativně reagovaly na CK 7 a desmin. Tato práce je první studií nádoru granulózních buněk vaječníku u bahnice.

\section{Acknowledgements}

We would like to thank Mr. Dane Velkavrh for help with immunohistochemistry. 


\section{References}

Ashorn P, Helle M, Helin H, Ashorn R, Krohn K 1988: Use of immunohistochemical staining panel for characterisation of ovarian neoplasms. J Clin Pathol 41: 12-16

Bernard DJ, Chapman SC, Woodruff TK 2001: Mechanisms of inhibin signal transduction. Recent Prog Horm Res 56: 417-450

Cordes DO, Shortridge EH 1971: Neoplasms of sheep: a survey of 256 cases recorded at Ruakura animal health laboratory. N Z Vet J 19: 55-64

Costa MJ, De Rose PB, Roth LM, Brescia RJ, Zaloudek CJ, Cohen C 1994: Immunohistochemical phenotype of ovarian granulosa cell tumors: absence of epithelial membrane antigen has diagnostic value. Hum Pathol 25: $60-66$

Gardner RB, Alcaraz A, Porter BF, Divers TJ 2005: Udder development, lactation and ascites in a ewe with an ovarian granulosa cell tumour. Aust Vet J 83: 486-488

Gift LJ, Gaughan EM, Schoning P 1992: Metastatic granulosa cell tumour in a mare. J Am Vet Med Assoc 200: $1525-1526$

Kennedy PC, Cullen JM, Edwards JF, Goldsmith MH, Larsen S, Munson L, Nielsen S 1998: Histological classification of tumours of the genital system of domestic animals. $2^{\text {nd }}$ ser. Armed Forces Institute of Pathology, Washington, DC, pp. 20-22

Kennedy PC, Miller RB 1993: The female genital system. In: Jubb KVF, Kennedy PC, Palmer N (Eds.): Pathology of domestic animals. $4^{\text {th }}$ ed. Academic Press, San Diego, pp. 349-470

McCluggage WG, Young RH 2005: Immunohistochemistry as a diagnostic aid in the evaluation of ovarian tumors. Semin Diagn Pathol 22: 3-32

MacLachlan NJ, Kennedy PC 2002: Tumours of the genital system. In: Meuten DJ (Ed.): Tumours in domestic animals. $4^{\text {th }}$ ed. Iowa State Press, Iowa, pp. 547-553

McEntee K 1990: Ovarian neoplasms. In: McEntee K (Ed.): In: Reproductive pathology of domestic mammals. Academic Press, New York, pp. 69-93

Norris HJ, Taylor HB, Garner FM 1969: Comparative pathology of ovarian neoplasms. II. Gonadal stromal tumours of bovine species. Vet Pathol 6: 45-58

Patrick DJ, Kiupel M, Gerber V, Carr EA 2003: Malignant granulosa-theca cell tumour in a two-year-old miniature horse. J Vet Diagn Invest 15: 60-63

Pelkey TJ, Frierson HF Jr, Mills SE, Stoler MH 1998: The diagnostic utility of inhibin staining in ovarian neoplasms. Int J Gynecol Pathol 17:97-105

Ramaekers F, Van Niekerk C, Poels L, Schaafsma E, Huijsmans A, Robben H, Schaart G, Vooijs P 1990: Use of monoclonal antibodies to keratin 7 in the differential diagnosis of adenocarcinomas. Am J Pathol 136: 641-655

Riccardi E, Grieco V, Verganti S, Finazzi M 2007: Immunohistochemical diagnosis of canine ovarian epithelial and granulosa cell tumors. J Vet Diagn Invest 19: 431-435

Sabočanec R, Čuljak K, Vrbanac L, Potočnjak D, Stanin D, Vranešić D, Karačić T 1996: A case of metastasizing ovarian granulosa cell tumour in the myocardium of a bitch. Acta Vet Hung 44: 189-194

Smith KC, Parkinson TJ, Long SE 1999: Abattoir survey of acquired reproductive abnormalities in ewes. Vet Rec 144: 491-496

Stabenfeldt GH, Hughes JP, Kennedy PC, Meagher DM, Neely DP 1979: Clinical findings, pathological changes and endocrinological secretory patterns in mares with ovarian tumours. J Reprod Fertil Suppl 27: 277-285

Vang R, Herrmann Me, Tavassoli FA 2004: Comparative immunohistochemical analysis of granulosa and Sertoli components in ovarian sex cord-stromal tumors with mixed differentiation: potential implications for derivation of Sertoli differentiation in ovarian tumors. Int J Gynecol Pathol 23:151-161 
Plate VII

Švara T. et al.: Malignant ... pp. 281-285

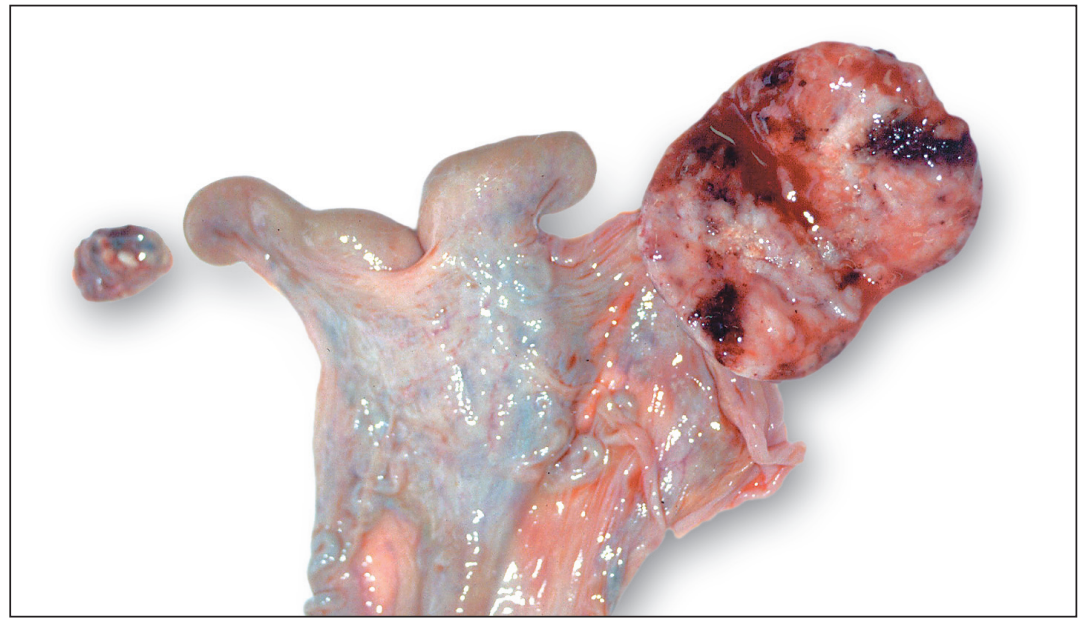

Fig. 1. Granulosa cell tumour; ovary; sheep. Enlarged right ovary with fine granular and greyishwhite cut surface and large areas of haemorrhages.

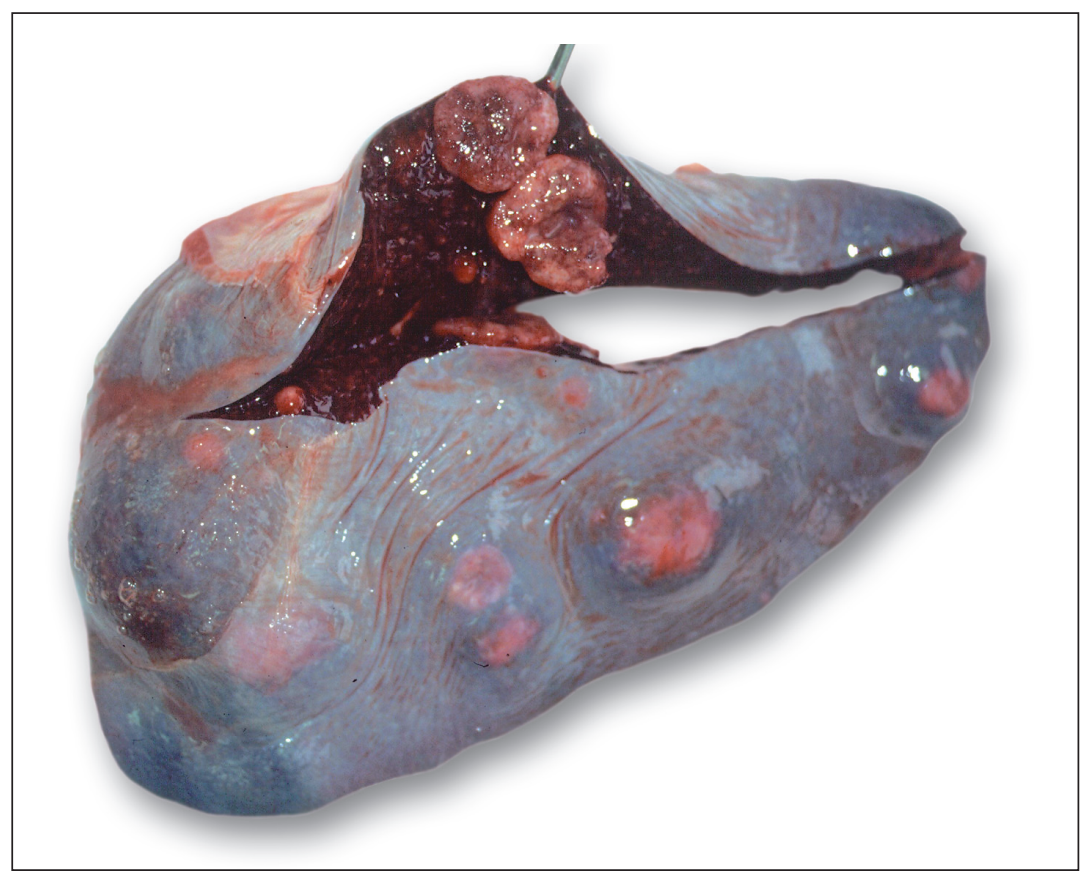

Fig. 2. Granulosa cell tumour; spleen; sheep. Multifocal metastatic nodules 


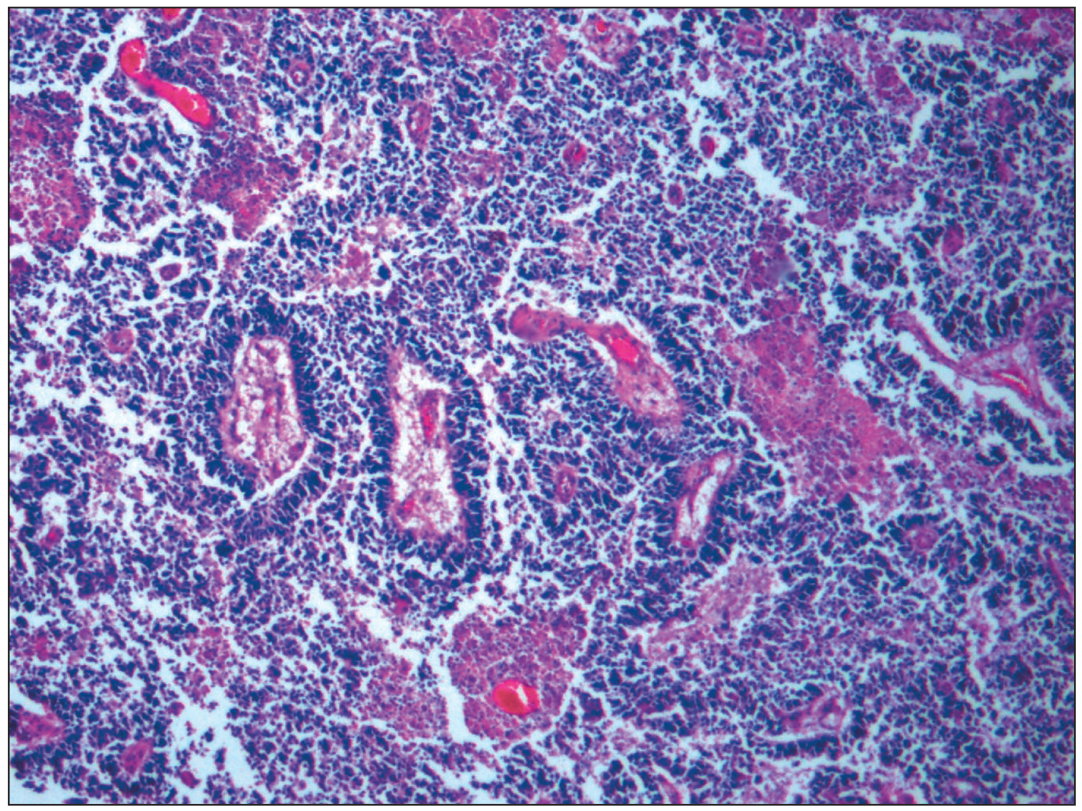

Fig. 3. Granulosa cell tumour of the right ovary; sheep. The tissue of ovary is totally replaced by tumour cells, arranged predominantly in follicles. Large necrotic areas are scattered in the tumour. HE staining, $\times 40$.

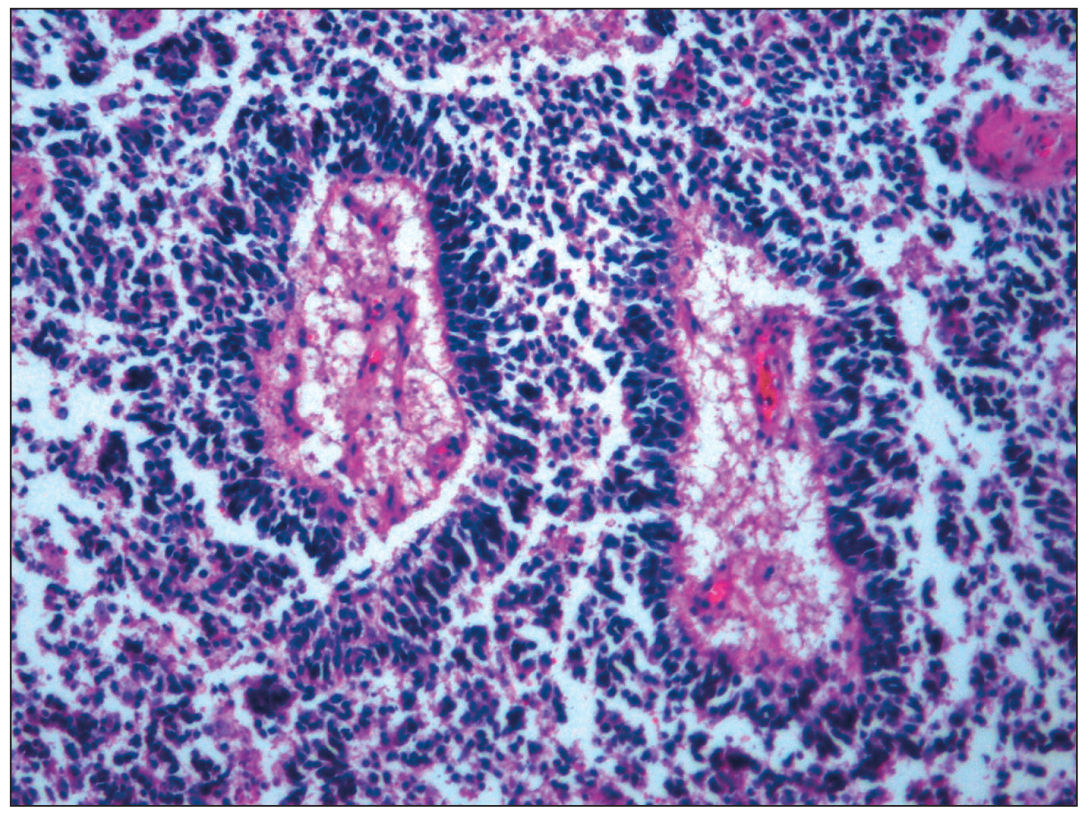

Fig. 4. Granulosa cell tumour of the right ovary; sheep. The area of tumour with Call-Exner body formation. HE staining, $\times 100$. 